\title{
Neuroendocrine alterations impair enamel mineralization, to oth eruption and saliva in rats
}

\section{Alterações neuroendócrinas interferem com a mineralizaçãodo esmalte, a erupção dentária e a saliva em ratos}

\author{
KikueTakebayashiSas saki* \\ Alberto Carlos Botazzo Delbem** \\ Oto ni el Antonio Macedo dos San tos*** \\ CarlosEduardoShimabucoro*** \\ Ana Cláu dia de Melo Stevanato Na ka mu ne* \\ João Cé sar Be dran-de-Cas tro**** \\ Ricardo Martins Oliveira-Filho*****
}

\begin{abstract}
AB STRACT: Neo na tal ad min is tra tion of monosodium glu ta mate (MSG) in rats causes defi inite neuroendocrine dis turbances which lead to al ter ations in many or gan sys tems. The pos si bil ity that MSG could af fect tooth and sal i vary gland phys i ol ogy was exam ined in this pa per. Male and fe male pups were in jected subcu ta ne ously with MSG (4 mg/g BW) once a day at the $2^{\text {nd }}, 4^{\text {th }}, 6^{\text {th }}, 8^{\text {th }}$ and $10^{\text {th }}$ day af ter birth. Con trol an i mals were in jected with sa line, fol low ing the same sched ule. Lower in ci sor erup tion was de ter mined be tween the $4^{\text {th }}$ and the $10^{\text {th }}$ postnatal days, and the erup tion rate was mea sured be tween the $43^{\text {rd }}$ and the $67^{\text {th }}$ days of age. Pilocarpine-stim u lated sal i vary flow was mea sured at 3 months of age; pro tein and am y lase con tents were thereby de ter mined. The an i mals treated with MSG showed sig nif $\mathrm{i}^{-}$ cant re duc tions in the sal i vary flow (males, $-27 \%$; fe males, $-40 \%$ ) and in the weight of submandbular glands (about $-12 \%)$. Body weight re duc tion was only about $7 \%$ for males, and did not vary in fe males. Sa liva of MSG-treated rats had in creased con cen tra tions of to tal pro teins and am y lase ac tiv ity. The erup tion of lower in ci sors oc curred ear lier in MSG-treated rats than in the con trol group, but on the other hand the erup tion rate was sig nif $i$ cantly slowed down. The in ci sor micro hard ness was found to be lower than that of con trol rats. Our re sults show that neo na tal MSG treatment causes well-de fined oral dis tur bances in adult hood in rats, in clud ing sal i vary flow re duc tion, which co existed with unal tered protein syn the sis, and dis turbances ofdentalmin eraliza tionand erup tion. These data sup port the view that some MSG-sen si tive hy po tha lamic nu clei have an im por tant modulatory ef fect on the factors which de ter mine cariessusceptibility.
\end{abstract}

DESCRIPTORS: So diumglu ta mate; Hypothala mic di sea ses; Dental physiology; Saliva; Rats.

RESUMO: Aadministraçãoneonataldeglutama tomonos só dico(MSG)emratos provoca dis túrb iosneuroendócrinos queacar retamal terações emvá rios sis temas or gâni cos. Nes tetrabalho, ava lia mosas re percus sões des setratamento so bre den tes e glân du las sa liva res. Ra tos ma chos e fême as re cém-nas ci dos foram in je ta dos com MSG (4 mg/g peso cor po ral, s.c.) uma vez ao dia nos $2^{\circ}, 4^{\circ}, 6^{\circ}, 8^{\circ}$ e $10^{\circ}$ dias após o nas ci men to; o gru po con t rolerecebeu soluçãosalina nomes mo es quema. Omomento da erup ção do in ci sivoinferiorfoidetermina do en treo $4^{\circ}$ e o $10^{\circ}$ dia de vida, e o rit mo de erup ção foi me di do en tre o $43^{\circ}$ e o $67^{\circ}$ dia. O flu xo de sa li va e o con te ú do sa li var de pro teína e ami la se fo ram de ter mi na dos sob es ti mu la ção com pi lo car pi na aos 3 me ses de ida de. Os ani ma is tra ta dos com MSG mos tra ram re du ções significativas do fluxo salivar (ma chos: $-27 \%$; fê me as: $-40 \%$ ) e do peso das glân du las submandibulares (cer ca de $-12 \%$ ). Ape nas em ma chos hou ve dis cre ta re du ção do peso cor po ral (7\%). A sa li va dos ani $m$ a is tra ta dos com MSG apre sen tou au men to na con cen tra ção de pro teínas to ta is e na ativi da de ami lá si ca.Aerup ção dosincisivos inferiores ocor reu mais pre co ce men te nos ra tos tra ta dos do que nos con tro les, po rém a taxa de erupçãoapre sen tou-se sig nifica tiva men te re duzi da. Ami cro du re za também foimenor nos anima is tra ta dos. Nos sos re sul ta dos mos tram que o tra ta men to de ra tos re cém-nas ci dos com MSG ca u sa um qua dro de fi ni do de al te ra ções buco-den ta is no ani mal adul to, tra du zi das por re du ção do flu xo de sa li va (sem re du ção da sín te se pro téi ca) e dis túr bios de mi ne ra li za ção e erup ção den tá ri as. Esses da dos apon tam para o im por tan te pa pel mo du la dor que cer tos nú cle oshipotalâmicos sen sí ve is ao MSG exer cem so bre os fa to res que re gu lam a sus ce ti bi li da de à cá rie.

DESCRITORES: Glutamato de sódio; Doenças hipotalâmicas; Fisiologia dentária; Sa liva; Ratos.

*PhD, Department of Ba sic Sci en ces, Di vi si on of Bi o che mistry; **PhD, De part ment of So c ial and Pe di a tric Den tistry; ***Undergraduate student; ****PhD, De part ment of Ba sic Sci en ces, Di vi si on of Physi ol ogy-Scho ol of Den tistry of Ara ça tu ba, SãoPauloStateUniversity.

***** PhD, Department of Phar ma cology, Insti tu te of Bi o me dical Sci en ces, Univer sity of SãoPa ulo. 
Sas sa ki KT, Delbem ACB, San tos OAM dos, Shi mabu co ro CE, Na ka mu neAC de MS, Be dran-de-Ca stroJC, Oliveira-Filho RM. Neu ro endocrinealterations im pairenamelmineralization, to oth eruptionand saliva in rats. Pes qui Odon tol Bras 2003;17(1):5-10.

\section{INTRODUCTION}

Monosodium glu ta mate (MSG) is a widely used food stuff flavouring com pound, es pecially in oriental food. In rats and mice, the neo na tal ad min is tra tion of MSG leads to extensive damage of certain hypothalamic nuclei, thus causing severe neuroendocrine disturbances in adulthood. The ab nor mal i ties, first ob served by Olney ${ }^{19}$ (1969), in cluded growth im pair ment, marked obe sity (which can de velop with out hyperphagia) and re duc tion of or gan weights, among others ${ }^{1,3}$. Marked re pres sion was observed in the ossification of developing endochondral bone, with the persistence of cartilagenous elements and chondrocytes ${ }^{9}$, reduced ra tio of min eral de po si tion, and slower bone maturation ${ }^{26}$.

The for mation, eruption and growth of teeth are processes under the concerted and timely in flut ences of several hormones, such as growth hormone $(\mathrm{GH})^{2,28,29}$ and thyroid ${ }^{14}$, sex $^{24}$, and adrenal hormones ${ }^{25}$. On the other hand, it is known that the development and the function of rodent sal $i$ vary glands de pend upon neurohormonal factors ${ }^{8}$, and that the salivary secretion in rats is under stronghy po tha lamic influence ${ }^{21}$.

Since the process of tooth formation and the den tal microenvironment are im por tant fac tors influencing caries susceptibility, the putative modulatory role of hypothalamus in these processes was eval $u$ ated by study ing the tooth micro hard ness, the sal i vary flow and the con cen tra tion of pro tein and am y lase in sa liva of con trol or neo natally MSG-injected rats.

\section{MATERIAL AND METHODS}

\section{Animals and treatments}

Ne o nate male and fe male Wistar rats were treated with 5 sub cu ta ne ous in jec tions of monosodium glutamate (MSG, Sigma Co., $4 \mathrm{mg} / \mathrm{g}$ body weight) dissolved in physiological saline. Injections were done once a day at the $2^{\text {nd }}, 4^{\text {th }}, 6^{\text {th }}, 8^{\text {th }}$ and $10^{\text {th }}$ day of life. Con trol an i mals were treated with the drug ve hi cle. Volumeinjected was al ways $0.02 \mathrm{ml} / \mathrm{g}$ BW.

Rats were weaned at 21 days and put thereafter on reg $u$ lar Purina rat chow and wa teradlibitum. The an imals were main tained on routinelaboratory care conditions $(12 \mathrm{~h}$ dark/light cycle, lights on 08:00 a.m., $24 \pm 2^{\circ} \mathrm{C}$ ). The ex per i men tal pro to col was ap proved by the Eth ics Com mit tee on An i mal Ex per imentation, UNESP School of Den tistry, Araçatuba.

\section{Tootheruption}

Inferior incisors eruption day was determined upon daily ex am i na tion from the $4^{\text {th }}$ up to the $10^{\text {th }}$ day of age. The rate of normofunctional tooth eruption was determined by ex am i na tion ev ery 2 days of the su pe rior in ci sors in the pe riod from 43 to 67 days of age. A starting mark at the gingival limit level was made under light ether an es the sia in the tooth enamel with a cylindrical bur and mensurations were then carried out following the method de scribed by Gerlach et $a l^{10}(2000)$.

\section{Salivary flow}

At 90 days of age, after $12 \mathrm{~h}$ fasting, the rats were anesthetized with sodium pentobarbital (Hypnol $^{\circledR}$, Cristalia, 40 mg/kg BW, IP). Salivary secretion was stimulated by pilocarpine nitrate (Sigma, $5 \mathrm{mg} / \mathrm{kg} \mathrm{BW}$, IP). Whole saliva was then collected $^{4}$ into preweighed ves sels and main tained on crushed ice during 20 min after the first drop had fallen. Vol umes were es ti mated by weight, assum ing the spe cific grav ity of sa liva to be $1.0 \mathrm{~g} / \mathrm{ml}$. After collection, the animalswere killed by excess pentobarbital anesthesia, and the parotid, submandibular and sublingual salivary glands were care fully dis sected out and weighed.

\section{Proteinandamylasedeterminations in saliva}

Total protein in saliva was determined by the method of Low ry et al..$^{15}$ (1951) and the sal i vary am ylase ac tiv ity by that of Caraway (1959). One unit of amylase activity is referred to as the amount of en zyme needed to hy dro lyze $10 \mathrm{mg}$ of starch in $30 \mathrm{~min}$ at $37^{\circ} \mathrm{C}$.

\section{Microhardness}

The up per and lower in ci sors were re moved and dissected free from any foreign adherent tissue. The right teeth were embeddedandlongitudinally placed into acrylic resin; the left teeth were sectioned and placed transversely into the resin ${ }^{23}$. In both sections (longitudinal and transversal), two in den ta tions were made, one on the crown and the other on the root, at the me dian por tion of enamel thickness. A microhardness tester Shimadzu HMV-2000 cou pled to a Knoop-like penetrator set was used with a $50 \mathrm{~g}$ load. Microhardnessresults are given in terms of $\mathrm{kgf} / \mathrm{mm}^{2} \times 10^{-3}$.

\section{Statis ticalanalysis}

Weight and microhardness data were studied by ANOVA and followed, wheneverappropriate, by Kruskal-Wallis or non-parametric multiple com- 
Sas sa ki KT, Delbem ACB, San tos OAM dos, Shi ma bu co ro CE, Na ka mu ne AC de MS, Be dran-de-Cas troJC, Oliveira-Filho RM. Ne u ro en do crinealterationsim pairena melmine ralization, to oth eruption and salivain rats. Pes qui Odon tol Bras 2003; 17(1):5-10.

parisons tests. A 2.01 version of the GraphPad InStat ${ }^{\circledR}$ software was used for this purpose.

\section{RESULTS}

Ponderal data are seen in Graph 1. The insert shows that neo na tal MSG treat ment caused a significant impairment of body weight gain of male rats, but this ef fect was not so clearly ev i dent in females. The weights of salivary glands relative to the body weight were differently influenced by MSG treat ment, as it caused an about $12 \%$ re duction of both male and fe male submandibular gland weights, a $21 \%$ reduction of male (but not of fe male) parotid glands, and did not in ter fere with the weights of sublingual glands of ei ther sex.

Salivary function studies are summarized in Table 1. MSG caused re mark able re duc tions in the pilocarpine-stimulatedsalivary flow, both in male $(-27 \%)$ and in female rats $(-40 \%)$. On the other hand, salivary contents of total protein and amylase ac tiv ity rose strongly, both in males (mean rise $31 \%$ ) and in fe males (mean rise $49 \%$ ).
The ef fects of neo na tal MSG ad min is tra tion on the erup tion of rat in ci sors are seen in Ta ble 2 . The total and daily rates of male rat tooth eruption were faster than those of females, and this difference was maintained or even somewhat accentuated as an ef fect of MSG. On the other hand, eruptionit selfoccurred significantly earlier in male or female rats treated with MSG than in their sex-matched con trols.

Table 3 shows the microhardness analysis of rat teeth. Over all, micro hard ness was sig nif i cantly higher for male than for fe male teeth, what ever the section or the anatomical region considered. Micro hard ness val ues ob tained in tooth lon gi tu dinal sections were higher than those in transverse sections, and also higher for the crowns when compared to the roots. We ob served that neo natal MSG treatment caused, in adulthood, an evenly lowered tooth microhardness, thus maintaining not only that sex dimorphism but also the differences pre vi ously seen re gard ing the tooth sec tions andanatomicalregions.

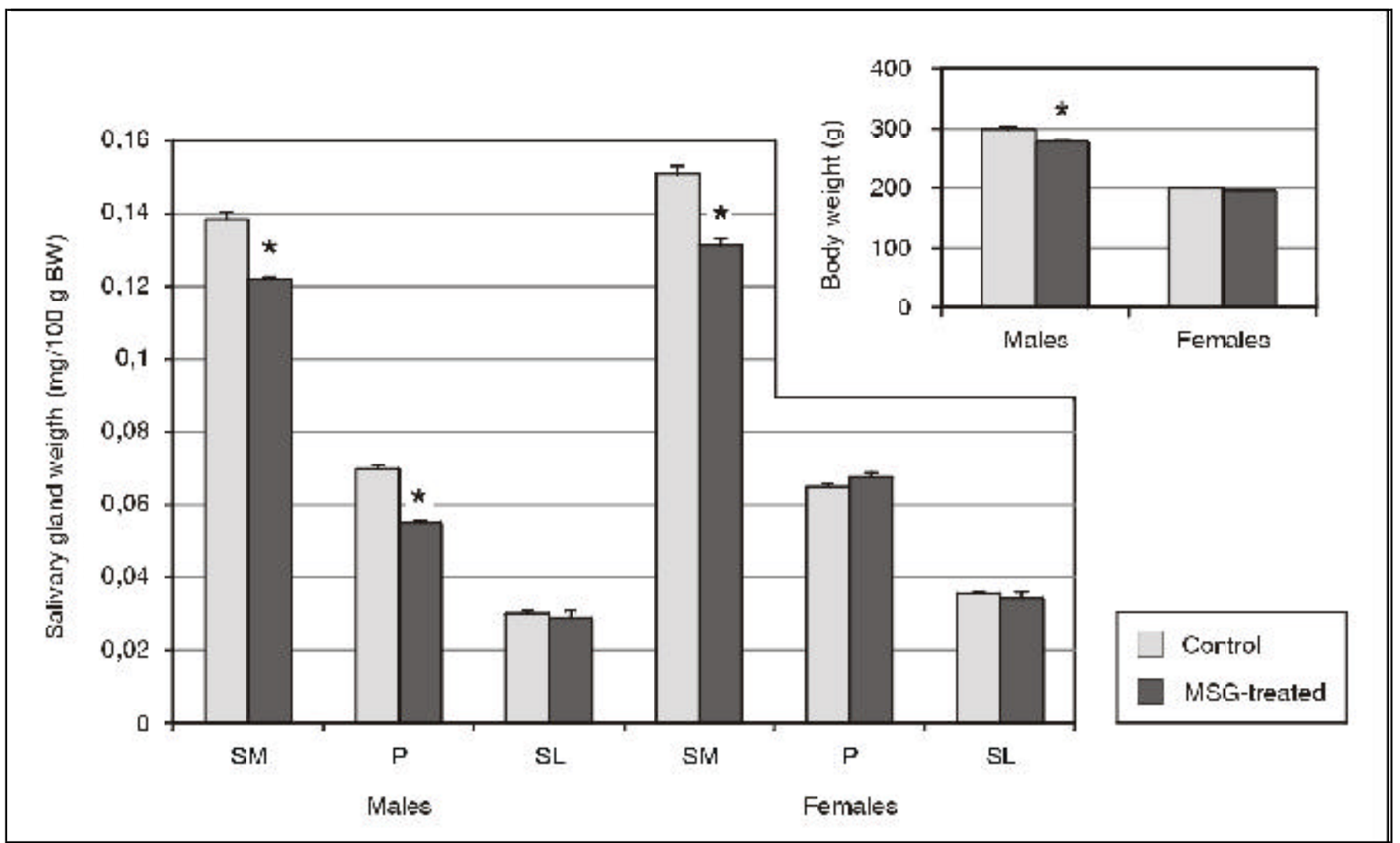

GRAPH 1 - Body and sa li vary gland we ights of con trols or rats ne o na tally tre a ted with mo no so di um glu ta ma te(MSG). The re la ti ve we ights of sub man di bu lar (SM), pa ro tid (P) and su blin gual glands (SL) aregi ven as mean \pm SEM of 10 animals for every group. The in sert shows the body we ights at sa cri fi ce (mean \pm stan dard er ror of the mean $(\mathrm{SEM}), \mathrm{n}=10)$. ${ }^{*} \mathrm{p}<0.01$ in re la ti on to the cor res pon ding con trol. 
Sas sa ki KT, Delbem ACB, San tos OAM dos, Shi mabu co ro CE, Na ka mu neAC de MS, Be dran-de-Ca stroJC, Oliveira-Filho RM. Neu ro endocrinealterations im pairenamelmineralization, to oth eruptionand saliva in rats. Pes qui Odon tol Bras 2003;17(1):5-10.

\section{DISCUSSION}

The early postnatal administration of monosodium glu ta mate (MSG) to rats is known to permanently damage neu rons in the hy po thalamic arcuate nucleus. The ensuing inappropriate brain-neuroendocrine-immune regulation was recently demonstrated to influ ence periodontal diseasesusceptibility and progression'. Being so, in this paper we examined the presumable con se quences of MSG treatment on salivary functional characteristics and on dental mineralization, which could con trib ute to den tal de cay.
Our re sults sho wed that male rats ne o na tally tre a ted with MSG not only had body we ight gain re ducti on butalsolower sub mandibular gland (SMG) we ights (Graph 1). Especially in rodents, it is well established thatSMGdevelopmentand differentiation are under the in flu en ce of a mul ti hor mo nal control $^{18}$, which plays a decisive role on its sexual di morphism. Since $70 \%$ of total saliva are from the $\mathrm{SMG}^{11}$, the hormonal imbalance triggered by MSG could ex pla in the re duc ti on of SMG we ight (Graph 1) and the impaired salivary response to pilocarpine stimulation (Table 1). In addition, it is conceivable

TABLE 1 - Sa li vary func ti ons of male and fe ma le rats. Re sults for con trols and rats ne o na tally tre a ted with mo no so di um glu ta ma te (MSG). Re sults are mean \pm stan dard er ror of the mean (SEM) of 16 ob ser va ti ons throug hout.

\begin{tabular}{llccc}
\hline \hline \multirow{2}{*}{ Groups } & $\begin{array}{c}\text { Salivary flow } \\
(\mu \mathrm{l} / \mathrm{min} \text { per } 100 \mathrm{~g} \mathrm{BW})\end{array}$ & $\begin{array}{c}\text { Total protein content } \\
(\mathrm{mg} / \mathrm{ml})\end{array}$ & $\begin{array}{c}\text { Amylase activity } \\
\left(\mathrm{U} / \mathrm{ml} \times 10^{-2}\right)\end{array}$ \\
\hline \multirow{2}{*}{ Control } & Males & $17.60 \pm 0.50^{\mathrm{a}}$ & $8.39 \pm 0.28^{\mathrm{a}}$ & $14.70 \pm 0.47^{\mathrm{a}}$ \\
\cline { 2 - 5 } & Females & $23.40 \pm 0.60^{\mathrm{c}}$ & $8.13 \pm 0.34^{\mathrm{a}}$ & $15.03 \pm 0.38^{\mathrm{a}}$ \\
\hline \multirow{2}{*}{ MSG-treated } & Males & $12.80 \pm 0.50^{\mathrm{b}}$ & $10.32 \pm 0.41^{\mathrm{b}}$ & $20.39 \pm 0.60^{\mathrm{b}}$ \\
\cline { 2 - 5 } & Females & $14.10 \pm 0.60^{\mathrm{b}}$ & $12.18 \pm 0.24^{\mathrm{c}}$ & $22.29 \pm 0.26^{\mathrm{c}}$ \\
\hline \hline
\end{tabular}

Me ans fol lo wed by dis tinct su pers cript let ters are sig ni fi cantly diffe rent from each ot her (ANOVA, $p<0.05)$.

TABLE 2 - Erup ti on of the in ci sors of male and fe ma le rats. Re sults for con trols and rats ne o na tally tre a ted with mo no so di um glu ta ma te (MSG). Re sults are mean \pm stan dard er ror of the mean (SEM).

\begin{tabular}{|c|c|c|c|c|c|}
\hline \multirow{2}{*}{\multicolumn{2}{|c|}{ Groups }} & \multicolumn{2}{|c|}{ Eruption rate $(\mathrm{mm})$} & \multicolumn{2}{|c|}{ Eruption observed (\% of the litter) } \\
\hline & & \multirow{2}{*}{$\begin{array}{c}\text { Total } \\
11.859 \pm 0.100^{\mathrm{a}}\end{array}$} & \multirow{2}{*}{$\begin{array}{c}\text { Per day } \\
0.566 \pm 0.0050^{\mathrm{a}}\end{array}$} & \multirow{2}{*}{$\begin{array}{c}\text { At the } 8^{\text {th }} \text { day } \\
25\end{array}$} & \multirow{2}{*}{$\begin{array}{c}\text { At the } 9^{\text {th }} \text { day } \\
75\end{array}$} \\
\hline$C_{9}$ & Males & & & & \\
\hline Control & Females & $11.488 \pm 0.141^{\mathrm{b}}$ & $0.549 \pm 0.0068^{b}$ & 44 & 56 \\
\hline \multirow{2}{*}{ MSG-treated } & Males & $11.416 \pm 0.085^{\mathrm{b}}$ & $0.542 \pm 0.0045^{b}$ & 53 & 47 \\
\hline & Females & $10.841 \pm 0.071^{\mathrm{c}}$ & $0.517 \pm 0.0036$ & 67 & 33 \\
\hline
\end{tabular}

Means fol lo wed by dis tinct su pers cript let ters are sig ni fi cantly dif fe rent from each ot her (ANOVA, p< 0.05). For the erup ti on rate and erup ti on day, data are from 16 ob ser va ti ons for every group.

TABLE 3 - Mi cro hard ness of in ci sor ena mel of male and fe ma le rats. Re sults for con trols and rats neonatallytreated with mo no so di um glu ta ma te (MSG). Re sults are mean \pm stan dard er ror of the mean (SEM) of determinationscarried out in 56 te eth for every group.

\begin{tabular}{l|llc|cc}
\hline \hline \multirow{2}{*}{\multicolumn{2}{c}{ Groups }} & \multicolumn{4}{c}{ Microhardness $\left(\mathrm{kgf} / \mathrm{mm}^{2} \times 10^{-3}\right)$} \\
\cline { 3 - 6 } \multicolumn{2}{c}{ Control } & $\begin{array}{c}\text { Longitudinal } \\
\text { section }\end{array}$ & $\begin{array}{c}\text { Transverse } \\
\text { section }\end{array}$ & Crown & \multirow{2}{*}{ Root } \\
\hline \multirow{2}{*}{ MSG-treated } & Males & $271.84 \pm 2.26^{\mathrm{a}}$ & $259.98 \pm 3.39^{\mathrm{d}}$ & $273.98 \pm 2.07^{\mathrm{a}}$ & $257.84 \pm 3.43^{\mathrm{d}}$ \\
\cline { 2 - 6 } & Females & $262.62 \pm 2.02^{\mathrm{b}}$ & $253.85 \pm 2.75^{\circ}$ & $263.44 \pm 2.07^{\mathrm{b}}$ & $253.03 \pm 2.69^{\mathrm{e}}$ \\
\hline \hline
\end{tabular}

Me ans fol lo wed by dis tinct su pers cript let ters are sig ni fi cantly diffe rent from each ot her (Krus kal-Wal lis, $p<0.05$ ). 
Sas sa ki KT, Delbem ACB, San tos OAM dos, Shi ma bu co ro CE, Na ka mu neAC de MS, Be dran-de-Cas troJC, Oliveira-Filho RM. Neu ro endocrinealterations im pair enamelmineralization, to oth eruptionand salivain rats. Pes qui Odon tol Bras 2003; 17(1):5-10.

that some re duc ti on in the den sity and/or res pon siveness of autonomic muscarinic receptors of the gland could con tribu te to the al te red res pon se.

As a part of the histomorphological and biochemi cal sex ual di mor phism of the sal ivary glands invar ious mammal species ${ }^{22}$, the number of muscarinic and $\beta$-adrenergic receptors in the SMG can be $25-51 \%$ higher in fe male than in male rats ${ }^{6}$, and this could ex plain the higher sal i vary flow of our con trol fe males (Ta ble 1). On the other hand, this sex dif ference dis ap peared in our MSG-treated an i mals, presumably as a function of the drug-induced al terations of cir cu lat ing lev els of go nadal steroids ${ }^{17}$.

Con cen tra tions of to tal pro teins and of amy lase ac tiv ity in sa liva of MSG-treated rats were significantly higher than those found in controls (Table 1). How ever, if these val ues are taken as a func tion of the salivary flow, such differences are blunted (for example, control males $=0.148 \pm 0.004$ and MSG-treated males $=0.132 \pm 0.005 \mathrm{mg}$ pro tein secreted/min per $100 \mathrm{~g} \mathrm{BW;}>0.1)$. These results suggest that the net synthesis and/or release of salivary proteins were not affected by the drug, and only the fluid pro duc tion was in fact re duced. On the other hand, the magnitude of protein in crease in saliva was undistinguishable from that showed by am y lase, thus sug gest ing that the specific pro tein which in creased as an ef fect of MSG treatment was largely amylase.

Regarding enamel mineralization, as observed in other tis sues and func tions, a rea son able de gree of sex di mor phism ex ists in the micro hard ness of the tooth enamel, that of males be ing higher than that of females. Though MSG treatment was able to significantly diminish both crown and root microhardness, those sex differences were not abol ished (Ta ble 3).

Among other fac tors pos si bly in volved, the hor monal im bal ances due to MSG treat ment con ceivably play a very important role. Pre- or postnatal hypothyroidism slows down dental development, leading to defects in the enamel which are observed later in life ${ }^{14}$. Interference with the growth hor mone $(\mathrm{GH})$ could also im pair the for ma tion and mineralization of the teeth, since GH receptorsare pres ent in di vid ing cells, preameloblasts, differ entiating preodontoblasts, and in secreting ameloblasts and odon to blasts of 45-day rat in ci sors and molars ${ }^{28}$. In ad di tion, GH de fi ciency re duces rRNA expression in preameloblasts and pre-odontoblasts $^{29}$ and the synthesis of two proteoglycans, decorin and biglycan, thus impairing the correct tooth for ma tion and mi nera lization ${ }^{30}$.
Over all, the hor monal al ter ations caused by neo natal treatment of rats with MSG most presumably interfered with several steps of tooth formation, including theintes tinalab sorption of $\mathrm{Ca}^{2+}$, and the synthesis of pro teins and proteoglycans which built up the extracellular ma trix and play a fur ther role in the process of dental mineralization. Also, the enzymes involved in amelogenesis could also be affected.

In fe rior in ci sors erup tion both in male and fe male rats oc curred at the $9^{\text {th }}$ postnatal day in con trols and at the $8^{\text {th }}$ day in MSG-treated an i mals (Ta ble 2). The limiting factor to den tal erup tion is the re sorp tion of alveolar bone, which forms a path for eruption and depends upon the formation and activity of osteoclast cells ${ }^{27}$. The process as a whole, me di ated through the expression of osteoprotegerin, is regulated by a del i cate hor monal bal ance be tween syn ergis tic (parathyroid hor mone, glucocorticoids) ${ }^{13,27}$ and antagonistic influences (estrogens, GH) ${ }^{2}$. Although the exact mechanism by which neonatal MSG caused an accelerated rat incisors eruption is at present an unresolved question, this might be the result of multifactorial-dependent, increased osteoclasticactivity.

The rates of incisor eruption were found to be slower in fe male than in male rats; neo na tal MSG treat ment caused a global re duc tion in these rates but did not interfere with the observed sex difference (Ta ble 2). It is known that erup tion reg u la tion in rats depends upon the balanced activity of cementoblasts and of periodontal ligament cells, which in turn are stim u lated by $\mathrm{GH}$ and inhibited by parathyroid hor mone (PTH) ${ }^{20}$. Even though in this experimental model the serum levels of PTH have not been stud ied yet, and the par tic i pa tion of corticoid hor mones can not be discarded ${ }^{16}$, our results can be par tially ex plained by the re duc tion of GH cir cu lat ing lev els caused by MSG'.

\section{CONCLUSION}

In conclusion, neo na tal MSG treat ment causes a se ries of oral dis tur bances in adult hood in rats, in clud ing sal ivary flow re duc tion and in ci sors mineralization and eruption disturbances. Our data sup port the view that the cohort of hor monal imbalances caused by hypothalamic malfunctioning can be ac counted for by many (if not all) of the alterations reported herein, and may culminate in highercaries susceptibility.

\section{ACKNOWLEDGEMENT}

Otoniel An to nio Macedo dos Santos has been recipient of a FAPESP scholarship (Grant no. 00/11959-7). 
Sas sa ki KT, Delbem ACB, San tos OAM dos, Shi mabu co ro CE, Na ka mu neAC de MS, Be dran-de-Ca stroJC, Oliveira-Filho RM. Neuro endocrinealterations im pairenamelmineralization, to oth eruptionand saliva in rats. Pes qui Odon tol Bras 2003; 17(1):5-10.

\section{REFERENCES}

1. Ali MM, Bawari M, Misra UK, Babu GN. Locomotor and learningde fi cits in adult rats expo sed to mo no so di um-L-gluta ma te du ring early life. Neu ros ci Lett 2000;284:57-60.

2. Au bin JE, Bon nel ye E. Oste o pro te ge rin and its li gand: a new paradigm for regulation of osteoclastogenesis and bone re sorp ti on. Oste o po ros Int 2000; 1 1:905-13.

3. Bellis le F. Glu ta ma te and the UMAMI tas te: sen sory, me tabolic, nutritionalandbehaviouralconsiderations. Areview of the li te ra tu re publis hed in thelast 10 ye ars. Ne u ros ci Bio be hav Rev 1999;23:423-38.

4. Be nar de MA, Fa bi an FW, Ro sen S, Hop pert CA, Hunt HR. A met hod for the col lec ti on of lar ge quan ti ti es of rat sa liva. $J$ Dent Res 1956;35:326-7.

5. Bre i vik T, Thra ne PS, Gjer mo P, Fon num F. Post na tal glutamate-induced centralnervoussystemlesionsalterperiodon tal di se a se sus cep ti bi lity in adult Wis tar rats. J Clin Periodontol2001;28:904-9.

6. Bylund DB, Mar tinezJR, Pi er ce DL. Re gu la ti on of au to nomic re cep tors in rat sub man di bu lar gland. Mol Phar ma col 1982;21:27-35.

7. Ca ra way WT. A sta ble starch subs tra te for the determination of amy la se in se rum and ot her body flu ids. Am J Clin Pathol 1959;32:97-9.

8. Dada MO, Camp bell GT, Bla ke CA. Effects of ne o na tal administration of monosodiumglutamate on so ma to trophs and growth hormone secre ti on in pre puber tal male and femalerats. Endo crinology 1984;115:996-1003.

9. Dhind sa KS, Omran RG, Bhup R. Effect of mo no so di um glutamate on the histogenesis of bone marrow in mice. Acta Anat 1978;101:212-7.

10. Ger lach RF, To le do DB, No va es PD, Mer zelJ, Line SRP. The effect of lead on the erup ti on ra tes of in ci sor te eth in rats. Archs Oral Biol 2000;45:951-5.

11. Holloway PJ, Willi ams RAD. Astudy of the oral se cre ti on of rats stimulated by pilocarpine. Archs Oral Biol 1965; 10:237-344.

12. Joseph BK, Sa va ge NW, Yonny WG, Wa ters MJ. Pre na tal expression of growth hormone receptor/bindingprotein and in su lin-like growth, fac tor-I (IGF-I) in the ena mel organ. Role for growth hor mo ne and IGF-I in cellu lar dif fe rentiation during early tooth formation? Anat Embryol 1994;189:489-94

13. Kanzawa M, Su gi mo to T, Ka na ta ni M, Chi ha ra K. Involvementofosteoprotegerin/osteoclastogenesisinhibitoryfac torin thestimulation of os te clastformation by pa rathyroid hormone in mouse bone cells. Eur J Endocrinol 2000; 142:661-4.

14. Kel ler EE, Sat her AH, Hay les AB. Den tal and ske le tal de velopment in various endocrine and metabolic diseases.J Am Dent Assoc 1970;81:415-9.

15. Lowry $\mathrm{OH}$, Rosebrough NS, Farr AL, Randall RJ. Protein me a su re ment with the Fo lin phe nol re a gent. J Biol Chem 1951;193:275-82

16. MachoL,JezovaD,ZoradS, FickovaM. Postnatalmonosodium glutamate tre at ment results in at te nuation of corti- costerone metabolic rate in adult rats. Endocr Regul 1999;33:61-7.

17. NemeroffCB, La martini eriCA, Ma son GA, SquilbRE, HongJS, BondySC.Markedreductioningonadalsteroidhormonelevels inrats treated ne ona tallywithmonoso dium-L-glu tamate: furtherevidencefordisruptionofhypothalamic-pituitary-gonadal axisregulation. Neuroendocrinology 1981;33:265-7.

18. Oliveira-FilhoRM, Fava-de-Moraes F, Minetti C, Moura NM, To le do MI. Mul ti hor mo nal con trol of the mu ri ne subman di bu lar gland. US/La tin Ame ri can Work shop on Sa li vary Re se arch. Pro ce e dings of a Con fe ren ce held at the Pan American Health Organization.Washington: C\&A Press; 1992. p. 109-30.

19. OlneyJW. Bra in lesions, obe sity and other dis turbances in mice treated with monosodium glutamate. Science 1969;164:719-21.

20. Ou yang H, McCa u ley LK, Berry JE, D'Errico JA, Stryhorn CL, So mer man, MJ. Res pon se of im mor ta li zed mu ri ne ce. mentoblasts/periodontal ligament cells to parathyroid hormoneand parathyroidhormone-related proteininvitro. Arch Oral Biol 2000; 45:293-303.

21. Renzi A, Lopes RA, Sala MA, Camargo LAA, Menani JV, Saad WA, et al.Morphological, morphometricand stereologi cal study of sub man di bu lar glands in rats with le si on of the an te ro ven tral re gi on of the third ven tri cle (AV3V). Exp Pat hol 1990;38:177-87.

22. Sa wa da K, Nou mu ra T. Effects of cas tra ti on and sex ste roids on sexually dimorphic development of the mouse sub man di bu lar gland. Acta Anat 1991;140:97-103.

23. Shinoda H. Effect of long-term administration of flu o ride on physico-chemicalproperties of the rat incisorenamel. Cal cif Tiss Res 1975;18:91-100.

24. Spi gelR, Sat her H, Hayles A. Cep halo me tric study of children with various endocrine diseases. Am J Orthod 1971;59:362-75.

25. Teng CM, Sob bows ki J, John ston LJr. The ef fect of cor ti so ne on the erup ti on rate of root re sec ted in ci sors in the rat. Am J Orthod Den to fac Orthop 1989;95:67-71.

26. Thompson MC, Norton NS, Rodriguez-SierraJF, Lippiello L. Growth hor mo ne-re le a sing hor mo ne de ple ti on in the fema le rat, si mi la ri ti es to aging. J Ge ron tol A Biol Sci Med Sci 1996;51:B83-90.

27. Wise GE, Gri er RL, Lump kin SJ, Zhang Q. Effects of de xa met ha so ne on to oth erup ti on in rats: diffe ren ces in in ci sor and mo lar erup ti on. Clin Anat 2001;14:204-9.

28. Zhang $\mathrm{CZ}$, Young WG, Waters MJ. Immunocytochemical localization of growth hormonereceptor in rat maxillary teeth . Archs Oral Biol 1992;37:77-84.

29. Zhang $\mathrm{CZ}$, Young WG, Li H, Robinson S, Waters MJ. Growth hormoneregulatesnucleolarorganizerregionsduring odontogenesis in the rat. $J$ Oral Pathol Med 1992;21:395-400.

30. Zhang CZ, Li H, Bar told PM, Young WG, Wa ters MJ. Effect of growth hor mo ne on the dis tri bu ti on of de co rin and bi glycan du ring odon to ge ne sis in the rat in ci sor. J Dent Res 1995;74:1636-43. 